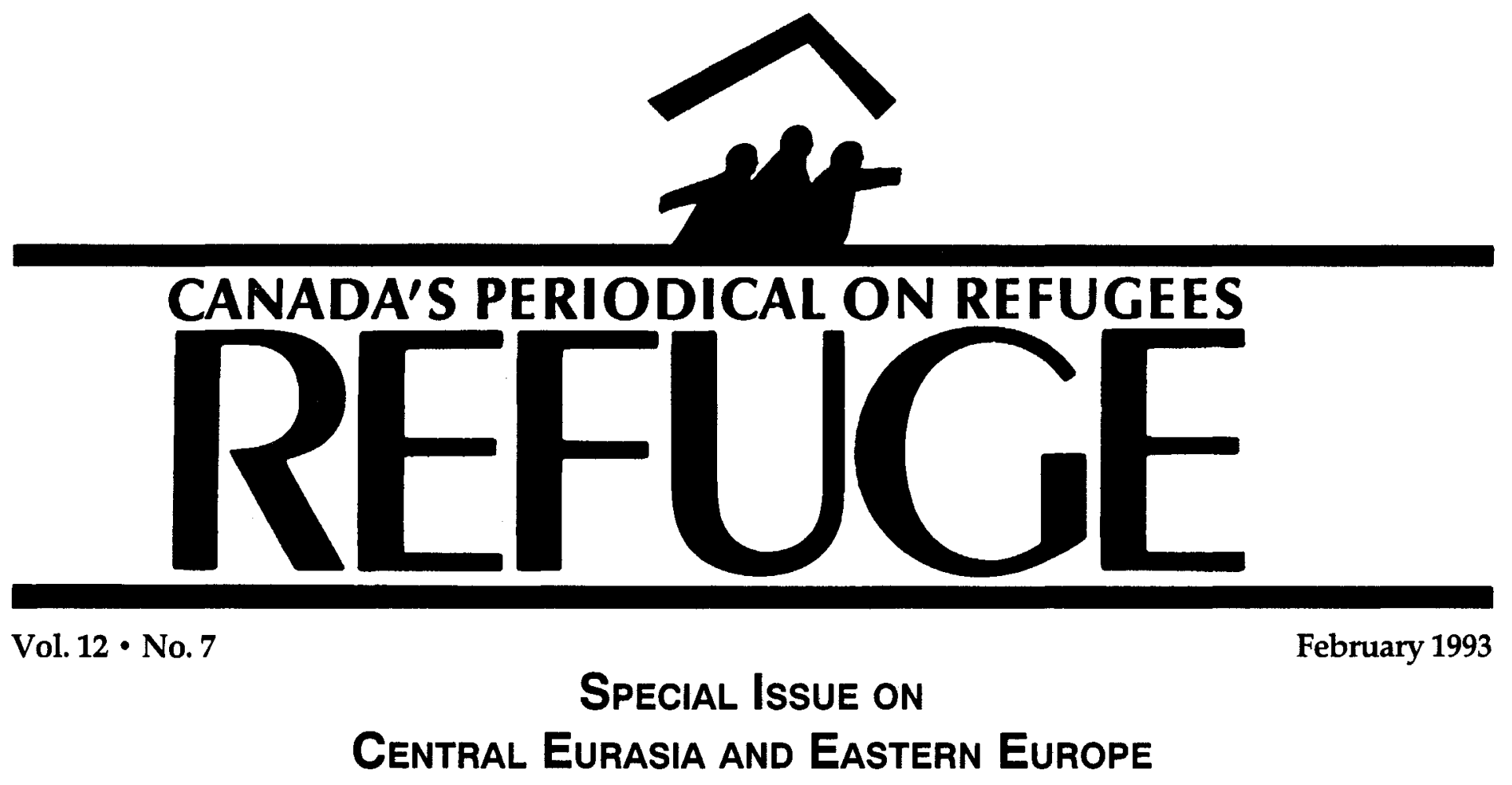

\title{
Ethnic Purification and Its Three Types of Refugees
}

Images of "ethnic cleansing" in Bosnia and the millions of internal and external refugees that it has produced are familiar to people throughout the world. The international community has been appalled by the reports of bloody massacres, rapes of young girls, concentration camps and massive uprootment of the Muslim population of this region. Unfortunately, what is happening in former Yugoslavia today can be replicated in a number of other regions of the former Soviet bloc countries that have received farless media coverage. Policies of ethnic purification have been adopted by nationalist governments in the Baltic, central Asia and the Caucasus. In some instances these policies have translated into discrimination against members of ethnic minorities in these states. In others, they have involved more violent clashes.

We can identify three types of refugees in the area. First, there are those refugees who have been displaced through armed confrontations. Among them are Croatians and Bosnian Muslims from former Yugoslavia, Armeni- ans from Azerbaijan, Azeries from Armenia, Ossetians from Georgia, Ingushetians from northern Ossetia (southern Russia), Greeks and Russians from Abkhazia (Georgia), Jews in central Asia and in southern Russia, and members of conflicting tribes in Tadjikistan.

Second, there are those refugees who are pushed out of their homes through less violent means. Among them are two million Russians who have been forced out of the Baltic, Central Asian and Caucasian states by such policies as denial of employment, of the right to educate their children in Russian, of citizenship, of a right to own property, and of franchise. Many Russian-speaking Jews in these regions have received the same treatment. However, unlike the Russians who flee predominantly to Russia, Jews have

\section{Contents:}

Ethnic Purification and Its Three Types of Refugees

Tanya Basok and Alexander Benifand

Forced Migration and Refugee Flows in Croatia, Slovenia and

Bosnia-Herzegovina Silva Meznaric and Jelena Zlatkovic Winter .........

Needy Guests, Reluctant Hosts? Refugee Women from the

Former Yugoslavia in Hungary Éva V. Huseby-Darvas.

Russian Policy and the Intensification of Civil Wars in

Georgia, Tajikistan and Moldova Alexander Benifand....

Jews in Moldova, Central Asia, Azerbaijan and Georgia Tanya Basok 16

Psychosocial Changes in East German Refugees

Ralf Schwarzer and André Hahn

Book Review: Refugee Communities John Sorenson ..... 
REFUEGE

YORK LANES PRESS

Centre for Refugee Studies

Suite 351 , York Lanes

York University

4700 Keele Street, North York

Ontario, Canada M3J 1P3

Phone: (416) 736-5843 - Fax: (416) 736-5837

Electronic Mail via Bithet Address:

REFUGE QYORKVMI

Vol. $12 \cdot$ No. 7

Editor

Howard Adelman

Issue Guest Editors

Tanya Basok

Alexander Benifand

Associate Editor

Valerie Ahwee

Assistant Editor

Stephanie E. Johnson

Circulation Assistant

Dominika Zakrzewski

Managins Editor

Arui S. Aruliah

Refuge is dedicated to the encouragement of assistance to refugees by providing a forum for sharing information and opinion on Canadian and international issues pertaining to refugees. Refuge was founded in 1981.

It is published ten times a year by York Lanes Press for the Centre for Refugee Studies, York University, Canada. Refuge is a nonprofit, independent periodical supported by private donations and by subscriptions. It is a forum for discussion, and the views expressed do not necessarily reflect those of its funders or staff.

All material in Refuge may be reproduced without permission unless copyrighted or otherwise indicated. Credit should be given to the author or source, if named, and Refuge. Submissions on related issues are welcome for publication consideration

Current subscription rates for one year (ten issues) are:

Canada $\quad$ Can $\$ 50.00$

All other countries U.S. $\$ 60,00$

Single issues are available at $\$ 6.50$ per copy.

Please enclose your purchase order or payment, made payable to York Lanes Press, with your order.

ISSN 0229-5113 opted to leave the area of the former Soviet Union and migrate to Israel, the United States or Canada and other countries. Most Germans from Central Asia would like to emigrate to Germany. Since Germany has set a limited annual quota for resettlement of ethnic Germans from the former Soviet Union, many have chosen to move to Ukraine and Russia in the meantime.

In the case of Jews, some of the means adopted to force them out of their home regions have included open assaults, threatening letters and telephone calls. However, most of these attacks have been aimed at individual families and there have not yet been any widespread pogroms against Jewish communities in these regions.

And finally, the third type consists of potential refugees or those who, for various reasons, have not left their homes yet, although they have experienced discrimination, harassment and, at times, violence. Among them are Jews throughout the former Soviet Union who have received invitations to migrate to Israel, but who are reluctant to move because of serious hardships the Soviet alia have experienced in Israel in the last few years. More than twenty million Russians are still found outside Russia and are expected to join the ranks of those who have already become refugees. However, the persistence of the institution of propiska (residency permit) in Russia prevents most of them from moving there. Over two million Germans and their families (which include non-Germans), dispersed throughout the territory of the former U.S.S.R., are also hoping to migrate to Germany. Their gradual resettlement may take over twenty years.
Israel and Russia have opened their doors wide to members of their own ethnic groups. Yet because of respective economic, political and social problems (rejection by the host population in the case of Israel) in these two countries, many of their potential refugees presently prefer to stay at home. This situation may change if they experience a stronger push by the ethnic majority in their countries to leave. Many of the Germans in Russia would leave for Germany now if Germany changed its policy, which is not likely in the near future.

Many of these refugees have been victims of extreme violence, but have not received international attention and support. Successful settlement of these refugees requires careful analysis of their needs and ways these needs can be met, as articles by Huseby-Darvas, Meznaric and Zlatkovic Winter, and Schwarzer and Hahn in this issue show. However, while the case of Bosnia has been the most dramatic example of ethnic cleansing in the former Soviet bloc countries, the articles by Benifand and Basok show that a potential for genocide against ethnic minorities exists in other parts of this region and that thousands of people can be turned into refugees by other means that are less bloody. In order to deliver adequate assistance to refugees, it is important to report on the violations of human rights of various ethnic minorities, on less violent strategies used to force them out of their home regions, and to monitor those conditions that convert potential refugees into real ones.

Tanya Basok and Alexander Benifand

\section{CRS Editorial Advisory Board}

\section{Central Eurasia and Eastern Europe Refugee Monitor Unit}

Audrey Alstadt, History, University of Massachusetts; Tanya Basok, Sociology/ Anthropology, University of Windsor, Alexander Benifand, Centre for Refugee Studies, YorkUniversity; RobertJ. Brym, Sociology and Centrefor Russianand East European Studies, University of Toronto; Sidney Heitman, History, Colorado State University; Mirjana Morokovasic, Centre national de la Recherche scientifique; Endre Sik, Social Science Information Centre, Budapest; Galina Soldatova, Institute of Enthnography and Anthropology, Russian Academy of Sciences, Moscow. 